\title{
ANTAGONISTIC BEHAVIOUR OF HORNED GREBES
}

\section{E. OTTO HOHN, 11511-78 Avenue, Edmonton, Alberta. T6C ON4}

Horned Grebes breed on small sloughs or ponds between Edmonton and Beaverhill Lake Alberta. The observations reported hare were made at a pool slightly less than 1 ha in area, separated by a secondary road from our acreage, $48 \mathrm{~km}$ east of Edmonton. Between 1967 and 1987 Horned Grebes nested on that pond each year from 1973 - 1978, in 1984 and possibly in a few other years when the author was absent during much of the breeding season.

In the morning of 21 May 1973 a pair of these grebes was present on the pond; they had no doubt been there for some time. In most years the species was first seen there about the beginning of May. A third (presumably male) Horned Grebe flew into the pond, landed, and almost immediately dived. When it surfaced, one of the paired grebes swam towards the intruder with head and neck lowered along the surface of the water in a posture like that depicted in Johnsgards' Diving birds (Fig. 36K). ${ }^{1}$ The intruder withdrew but was pursued by the territorial bird, swimming fast or at times diving and emerging near the intruder, and flapping its wings whenever it came close. During $10-15$ minutes of observation, the intruder remained on the pond but kept still, well away from the pair, partly hidden by tufts of the shoreline vegetation. It probably left soon after, for by 2 June the pair, sole occupants of the pond, had a nest which one of them was incubating. The episode was evidently an example of territorial defence.
Aggressive behaviour of a grebe towards Ruddy Ducks was observed on the same pond on three occasions in 1984. On the morning of 2 June a Horned Grebe repeatedly attacked a pair of Ruddy Ducks in the posture used to defend against other Horned Grebes, pursuing them in rushes above the water or at times diving toward them causing the ducks to make frantic short distance escapes. The grebe showed no concern about several pairs of Redheads also present at the time.

During the evening of 29 June a grebe repeatedly chased two male and two female Ruddy Ducks one at a time and in the same manner. On the morning of 2 July the male grebe (its head furnishings were still in full breeding plumage while those of its mate were by now much paler) was seeking food swimming with head submerged and making occasional short dives. Several times he interrupted those activities to rush at a male Ruddy, approaching the duck both above and under the water, always causing the duck to swim or dive away for a short distance. As on the previous occasions ducks of other species did not arouse the grebe's antagonism. Perhaps Ruddies, because they are small divers, somewhat similar in general colour to the grebes, provide enough grebe-like stimuli to be treated as if they were conspecific birds.

1 JOHNSGARD, P.A. 1987. Diving birds of North America. Univ. of Nebraska Press, Lincoln. 